PhDr. ef ThDr. Maroš Šip, PhD.

Pravoslávna

bohoslovecká fakulta

Prešovská univerzita v Prešove
Eliminacja wykluczenia społecznego, red. M. Duda, K. Kutek-Sładek, Kraków 2017, s. 21-25 (Praca Socjalna w Teorii i Działaniu, 3).

DOI: http://dx.doi.org/10.15633/9788374385824.02

\title{
Úloha rodiny pri resocializácii bývalých členov siekt
}

\author{
The role of the family in social reintegration of former \\ members of cults
}

\begin{abstract}
Alternative religiosity does not always offer its members a comfortable search for the transcendent. There are many reasons, on the basis of which negative consequences can result. In the first place there is a loss of identity of the individual in the movement and
\end{abstract}

we should also not forget the correction or even elimination of social ties with relatives or friends.

Keywords: social advice, alternative religiosity, human being, cult

Rodina nesporne tvorí základné jadro pri socializácii človeka v spoločnosti. Jej úlohou je pozitívnym príkladom formovat morálne a etické povedomie detí a pripravit ich na život v societe. Pri výchove sa zameriavame nielen na celistvé rozvíjanie osobnosti a autonómie dietała, ale ho aj starostlivo vedieme k hodnotám, normám a kultúre spoločnosti. Zretelne stanovujeme hranice pre sociálny rozvoj, pomáhame nájst rovnováhu medzi objektívnym a subjektívnym nazeraním na vlastnú osobu. Ak v detskom svete absentujú pozitívne vzory, zdravá asertivita, sebaúcta, empatické schopnosti či zručnost’ vytvárat’ si priatel'stvá $s$ rovesníkmi, neskôr v dospelosti tieto negatíva môžu mat fatálne následky pre d’alšiu kvalitu života v spoločnosti.

Pri socializácii za nemenej dôležité považujeme, aby sa dietatu od samotného začiatku povedalo, čo je percipované ako správne a čo nesprávne, (samozrejme v kontexte konvenčných noriem spoločnosti-poznámka naša). Týmto spôsobom 
dosiahneme vysokú úroveň vedomostí o morálnych hodnotách, ktorými sa riadi a správa podla nich spoločnost.' ${ }^{1}$

Podla Rousseaua ${ }^{2}$ samotná socializácia spočíva v tom, že sa od raného detstva učíme materinskému jazyku, symbolom, viere a hodnotám predostretých rodinou. Po čase sa deti socializujú v spoločnosti a spoznávajú nových ludí, komunikujú s nimi a nadväzujú nové vztahy. Vzájomná reakcia pomáha rozvíjat’ osobné ja. Učíme sa dodržiavat' isté pravidlá, normy a zvyklosti našej kultúry. Vidíme v sebe to, čo si myslíme, že v nás vidia i ostatní. Ráno vstaneme a pozrieme sa do zrkadla a hráme rolu, ktorá sa od nás očakáva. Sme však individuálne bytosti majúce vlastnú skúsenost’ s rozvíjajúcou sa vlastnou identitou. Sme osoby, ktoré disponujú kreatívnym myslením, fantáziou, ale aj myslením kritickým. Dokážeme povedat', čo sa nám páči a čo nie. Dokonca máme možnost' si vybrat’ ako budeme konat’ v každej situácii.

Na základe nášho myslenia sa neskôr snažíme adaptovat’ v prostredí, urobit’ správne samostatné rozhodnutia a nestat’ sa závislými od rozhodnutia ostatných. Ale čo ked' vol'ba slobodného rozhodnutia, myšlienky a opatrenia podniknuté v spoločnosti sa nestretnú s pozitívnym ohlasom? A čo s dietatom vyrastajúcom v málo podnetnom a dysfunkčnom prostredí, ktoré za samostatnost', snahu a jedinečnost' je neskôr rodinou a spoločnostou nedocenené? Je len prirodzené, že hladá miesto, kde ho príjmu, a osoby, ktoré ho vypočujú.

Labilnejší jedinci, prechádzajúci obdobím smútku (strata rodinného príslušníka, blízkej osoby...), strata zamestnania, hádky s rodičmi, naštrbené rodinné vztahy, nepochopenie osobnosti, manželská kríza a iné negatíva sú vhodným lákadlom pre osoby vel'koryso sa zhostujúce úlohy ochrancu pred problémami. Stačí tak málo $\mathrm{k}$ ich osobnému štastiu: Vytvorenie novej identity a získanie novej rodiny starajúcej sa o svojho strateného a znovu nájdeného syna/dcéry.

V takomto prípade trpí nielen osoba, ktorá sa dala zlákat na nový nábor k organizácii, ale aj rodina. Rodičia sú prvými aktivizátormi pri znovuzískaní syna/dcéry zo sekty. Niekedy to urobia radikálnym riešením, teda násilným odchodom/odvlečením zo skupiny (čo nepovažujeme za príliš dobré riešenie) alebo požiadajú o pomoc výstupového poradcu, a ten krôčik po krôčiku pomáha členovi organizácie pripravit’ sa na výstup (opustenie sekty). V tomto prípade otázka znie: Dokáže sa opätovne resocializovat’ v spoločnosti odlišnej od zmýšlania, kultúry, hodnôt a mravov organizácie? Z nášho pohladu záleží

1 Pozri J. C. Borsa, O Papel da Escola no Processo de Socialização Infantil, „Psicoglobal - Psicologia.com.pt." 142 (2007), s. 1.

2 N. Ruosseau, Self, symbols, and society, Latham 2002, s. 9-20. 
od dížky pobytu v organizácii a tým pádom i od dížky psychickej adaptácie ${ }^{3}$. Ako teda pomôžeme ex-členovi sekty? Ako mu môže pomôct rodina? Na položené otázky sa pokúsime odpovedat'v nasledujúcich riadkoch.

Osoba žijúca dlhší čas v sekte (možno ju nazvat kultom, náboženskou organizáciou alebo novým náboženským hnutím) nemá často o živote v majoritnej spoločnosti vela poznatkov. Je to do väčšej či menšej miery zapríćinené aj filozofiou nového náboženského hnutia, pretože je dôležité pracovat preň, a nevenovat príliš času a osobného volna iným aktivitám mimo „novej“ komunity. V tomto kontexte platí, že tak, ako sa vyvíja dieta po celý svoj život, paritne sa rozvíja i osobnost dospelého jedinca a nesporne i celá spoločnost'. Mení sa myslenie ludí a ich pohlad na dodržiavanie zákonov a mravov.

Dôležitým aspektom v organizácii je duchovný rast, izolovanie od okolitého sveta (kontrola), dodržiavanie prísnych pravidiel, zbavenie sa kritického myslenia a vytvorenie pseudo-identity. V kulte sa formuje "nový“ človek. Ponúka sa mu materiálna a psychická „pomoc“ a samozrejme, nový spôsob života. To spôsobuje závislost na komunite. Po opustení tejto komunity sa cíti stratený. Nevie, ako má začat deň, komu sa zverit', s kým sa priatelit', na koho sa obrátit. Je dezorientovaný. Významnú rolu zohráva pri jeho znovu-adaptovaní sa rodina. Rodičia alebo súrodenci mu pomáhajú zvládat problémy nesamostatnosti, obnovit zdravotné a sociálne poistenie, nájst si zamestnanie, nastúpit opätovne na strednú školu, na univerzitu alebo zájst’ s ním na nákupy, $\mathrm{k}$ lekárovi a pod. Sám to často nezvládne. Trpezlivost̉ a láska sú dôležitými atribútmi resocializácie. Môžeme to prirovnat k pomoci rodičov snažiacich sa socializovat narodené dieta. Malá bytost' spočiatku nevie hrýzt', sediet', chodit, obliect sa. Rodičia ho učia primárnym zručnostiam. Identický postup sa núka aj pri resocializácii ex-člena.

Pre ex-člena sekty je teda dôležité, aby sa po návrate $\mathrm{k}$ rodine sám identifikoval..., kto som? Niekedy sa osobná identita nemusí zhodovat's identitou, ktorú očakávali rodinní príslušníci. V niektorých prípadoch noví členovia pri vstupe do sekty menia vzhlad ${ }^{4}$, a nemusia sa automaticky vrátit k pôvodnému výzoru. Ex-členovia sa nemusia opätovne vrátit $k$ svojim profesionálnym alebo edukačným cielom. Je preto nevyhnutné, aby rodina vytvorila také harmonické prostredie, kde sa osoba bude i nad’alej rozvíjat a integrovat do spoločnosti. Poradenstvo a psychoterapia je užitočná ako pre ex-člena, tak aj pre rodinu.

\footnotetext{
3 Alebo psychickej manipulácie. Ide o nevyhnutné a často nútené aktivizovanie sa v duchu filozofie hnutia, organizácie.

4 Napr. členovia ISKCON-u. Tzv. Hare Krišna, kde si vyholia takmer úplne hlavu a radikálne zmenia aj šatník.
} 
Dozvedia sa o živote v kulte, čím sa zredukuje pocit hanby, viny, vyriešia sa konflikty v rodine a vypracuje jednotný plán intervencie. ${ }^{5}$

Títo ludia sa snažia opätovne koexistovat' so spoločnostou, preto je nevyhnutné poznat' suportívne atribúty pri opätovnej fáze resocializácie. Podla Hawortha ${ }^{6}$ (What is Cult Information Centre CIC), generálneho tajomníka pre Kultové informačné centrum je potrebné:

1. Prijímat' bezpodmienečnú lásku a podporu - cítit sa normálne.

2. Rozprávat to, čo je sympatické a/alebo empatické ušiam - pochopenie.

3. Schopnost’ zúčastňovat’ sa na vlastnej rehabilitácii - cítił sa hodnotne.

4. Opätovne podporit’ ex-člena v slobodnom myslení - cítit bezpečie.

5. Hovorit' o lud’och, ktorých stretol v kulte - vybudovanie dôvery.

6. Naučit ho hovorit jazykom, akým hovoríme my - prijatie.

7. Mat' svoje miesto v spoločnosti, v živote, vol’ne sa pohybovat'.

8. Poskytnút príležitost' pre prácu - potreba rešpektu.

Z doteraz povedaného vyplýva, že aj rodina sa musí podielat pri plánovanej intervencii ex-člena v spoločnosti. Nemôžu žiadat', aby fázou resocializácie prechádzal sám, bez opory. Výskumy naznačujú, že mnoho bývalých členov siekt sa vd’aka podpore blízkej osoby (osôb) dokázalo stotožnit so svojou „pravou“"7 identitou a zaradit do bežného kolobehu spoločnosti. Nesmieme zabúdat' na jeden dôležitý fakt. Rodičia by mali pochopit zmysel a rozhodnutie svojej ratolesti, prečo sa vôbec rozhodla zanechat pôvodný život a odíst' do organizácie, čo bolo spúštačom pre alternatívny spôsob života?!

\section{Bibliografia}

Borsa J. C., O Papel da Escola no Processo de Socialização Infantil, „Psicoglobal - Psicologia. com.pt.“ 142 (2007), s. 1-5.

Duda M., W stronę wzmocnienia. Rodzina chrześcijańska w dobie zmian, Kraków 2011.

Hangoni T., Fenomén spravodlivosti v kontexte krestanskej sociálnej práce, [w:] Prawosławie jako czynnik odnowy tradycyjnych chrześcijańskich wartości w Unii Europejskiej (świadectwo i męczeństwo). II. rocznik: Kasztel w Szymbarku K. Gorlic, 9.12.2014, ed. J. Husár, Gorlice 2014, s. 76-83.

Pasternáková L., Rodina ako primárny činitel vzniku hodnôt, [w]: Prínos spoločenských vied k rozvoju znalostnej spoločnosti: medzinárodné kolokvium organizované Katedrou humanitných vied Stavebnej fakulty STU: zborník vedeckých prác, Bratislava, s. 114-119.

\footnotetext{
www.dallascult.com (3.04.2015).

www.cultinformation.org.uk (3.04.2015).

Tu máme na mysli stav pred vstupom do sekty.
} 
Ruosseau N., Self, symbols, and society, Latham 2002.

Dubrow-Marshall L. J., Emotions related to destructive sect involvement - families of cultists, ttp://dallascult.com/?page_id=426 (3.04.2015).

Haworth I., Caring for cult victims, http://cultinformation.org.uk/article_caring-for-cultvictims.html (3.04.2015). 
4. Uniwersytet Papieski 